\title{
CORRELATION AMONG GRAMMAR MASTERY AND VOCABULARY SIZE TOWARD TRANSLATION ABILITY ON REPORT TEXT
}

\author{
Fuyudhatul Husna ${ }^{1}$, Hesty Widiastuty ${ }^{2}$, Aris Sugianto ${ }^{3}$ \\ 1,2,3 State Islamic Institute Palangka Raya Indonesia \\ ${ }^{1}$ fuyudhatulh@gmail.com, ${ }^{2}$ hesty.widiastuty@iain-palangkaraya.ac.id, ${ }^{3}$ aris.sugianto@iain- \\ palangkaraya.ac.id
}

\begin{abstract}
The crucial problem of translating Indonesia to English language are the students' lack of knowledge and mother tongue (source language) that two of them are grammar and vocabulary. The researcher focused to measure the correlation among grammar mastery and vocabulary size toward translation ability on report text at seventh semester students in State Islamic Institute of Palangka Raya that use quantitative method with a correlational design. The researcher's instruments were three test which were grammar mastery, vocabulary size, and translation test that were tested to the 32 students' translation class in academic year 2017/2018. The numerical data were analyzed by Pearson Product Moment that showed that: (1) the most students got "fail" (43.75\%) grammar mastery, (2) the most students got "excellent" (46.875\%) vocabulary size, (3) the most students got "enough" (87.5\%) translation ability. The significant correlation among three variables were proved by correlation coefficient 0.604 (strong category), Fchange $>$ Ftable $=8.349>3.33$, and the contribution of grammar mastery and vocabulary size delivered $36.5 \%$. Thus, it sums that students' grammar mastery and vocabulary size correlate with the quality of students' translation ability on report text at seventh semester students in academic year 2017/2018.
\end{abstract}

Keywords: Grammar Mastery, Vocabulary, Translation

\section{INTRODUCTION}

The four skill of language is the fundamental skill necessary for language with different functions and advantages to communicate. The four skills need the equipment and the other component to support the efficiency of speech. The two elements of language are Grammar and Vocabulary. The can call by language equipment to help the skills; reading, speaking, listening, and writing.

The first is grammar. According to Azam (2014, p. 62) explain that grammar is a thing to express the necessary part that gives the essential to language. As cited in Debata (2013, p. 483), grammar defines the system and the way of gathering of words that it will be created as wonderful sentence. He supposes between people who use grammar and who do not use grammar with two bikers. The first biker just knows how to bike without knowing the engines' working. On the contrary, second biker understands both how to bike and engines' working. It makes second biker easier to repair than first biker when some trouble comes. According to Richards \& Schmidt (2010, p. 251), grammar is the way of word and phrases as a language system that are bounded into sentence. Based on the grammar interpretation above, the researcher sums that grammar is a thing or system to support the English language study with specific rules to express the comprehending word in a sentence. 
The second is vocabulary. According to Azam (2014, p. 63) stated that vocabulary is the property and the equipment of language. Hasan \& Subekti (2017, p. 56) state that Vocabulary means words that someone knows then use those (words) to communicate with others in a particular language. In communication, people need language production to send a message or information. According to Berg $(2014$, p. 1), the total number language in the world is 7100 . When people communicate with the other country, they should translate it with their mind and ability to comprehend the information.

In research article of Jixing (2013, p. 108) also describe that translation register the point to transfer the information from SL into TL. He believes The concept of excellent proportionate of translation is the closest essential of meaning and style. Some phenomena in real life show that the mark of students IAIN Palangka Raya of Indonesia - English translation class lower than the mark of English-Indonesia translation class. The researcher did the pre-interview with some students' to make sure the crucial problem of translating Indonesia into the English language, then they believed that it depended on the target language. Because of Indonesian learning English as a foreign language. So when the students translate the SL into TL, the mother language style is still followed. Also, it supported by research journal of Utami (2017, p. 192), when students' transference sentence pattern of Indonesia - English, there is the two problem, which are the students' mother tongue (SL) and lack of knowledge.

Based on the explanation, the researcher sums translation is a process of exchangeable oral and written messages from source language (SL) to target language (TL). The concept of grammar, vocabulary, and translation show there is a correlation among grammar mastery and vocabulary size on translation ability. Grammar and vocabulary as equipment language and the component language will be affected on an English translation.

\section{METHOD}

The researchers used quantitative method with correlational design. According to Creswell (2012, p. 338), the correlation had been a type of non-experimental research method that assessed and understood the numerical data relationship between two or more variable.

The researcher's instruments were three test which were grammar mastery, vocabulary size, and translation test that were tested to the 32 students' translation class in academic year 2017/2018. All test used Google Form. It saw in table below:

Table 1. Content Specification of Research Instruments

\begin{tabular}{ccccc}
\hline No & $\begin{array}{c}\text { Instrument } \\
\text { Name }\end{array}$ & $\begin{array}{c}\text { Language Skill } \\
\text { and Component }\end{array}$ & $\begin{array}{c}\text { Item of } \\
\text { Test }\end{array}$ & $\begin{array}{c}\text { Type of } \\
\text { Instrument }\end{array}$ \\
\hline \multirow{2}{*}{$\begin{array}{c}\text { Longman } \\
\text { Preparation } \\
\text { Course for } \\
\text { TOEFL }\end{array}$} & Grammar Mastery & 40 Items & $\begin{array}{c}\text { Multiple } \\
\text { Choice }\end{array}$ \\
\hline 2 & $\begin{array}{c}\text { Vocabulary Level } \\
\text { Test }\end{array}$ & Vocabulary Size & 90 Items & $\begin{array}{c}\text { Matching } \\
\text { Test }\end{array}$ \\
\hline 3 & Translation Test & Translation Skill & $\begin{array}{c}1 \\
\text { Paragraph }\end{array}$ & $\begin{array}{c}\text { Translate an } \\
\text { Essay }\end{array}$ \\
\hline
\end{tabular}

\section{RESULTS AND DISCUSSION}




\section{Results}

\section{Result of Grammar Mastery Test}

In this research, the quantity of Grammar mastery test was 40 items that adopted by Longman Preparation Course for TOEFL. The researcher used the multiple-choice and error analysis category for 32 students of the Indonesia-English Translation class. The test was conducted on Wednesday, 13th of January 2021 by using Google Form.

Table 2. The result of Grammar Mastery Score as variable X1

\begin{tabular}{|c|c|c|c|}
\hline No & Code & X1 & $\mathbf{X}^{2}$ \\
\hline 1 & S-1 & 30 & 900 \\
\hline 2 & S-2 & 50 & 2500 \\
\hline 3 & S-3 & 77.5 & 6006.25 \\
\hline 4 & S-4 & 27.5 & 756.25 \\
\hline 5 & S-5 & 75 & 5625 \\
\hline 6 & S-6 & 15 & 225 \\
\hline 7 & S-7 & 35 & 1225 \\
\hline 8 & S-8 & 45 & 2025 \\
\hline 9 & S-9 & 42.5 & 1806.25 \\
\hline 10 & S-10 & 40 & 1600 \\
\hline 11 & S-11 & 35 & 1225 \\
\hline 12 & S-12 & 45 & 2025 \\
\hline 13 & $S-13$ & 30 & 900 \\
\hline 14 & S-14 & 22.5 & 506.25 \\
\hline 15 & S-15 & 82.5 & 6806.25 \\
\hline 16 & S-16 & 50 & 2500 \\
\hline 17 & S-17 & 30 & 900 \\
\hline 18 & S-18 & 95 & 9025 \\
\hline 19 & S-19 & 40 & 1600 \\
\hline 20 & S-20 & 55 & 3025 \\
\hline 21 & S-21 & 32.5 & 1056.25 \\
\hline 22 & S-22 & 27.5 & 756.25 \\
\hline 23 & S-23 & 27.5 & 756.25 \\
\hline 24 & S-24 & 70 & 4900 \\
\hline 25 & S-25 & 35 & 1225 \\
\hline 26 & S-26 & 62.5 & 3906.25 \\
\hline 27 & S-27 & 97.5 & 9506.25 \\
\hline 28 & S-28 & 40 & 1600 \\
\hline 29 & S-29 & 32.5 & 1056.25 \\
\hline 30 & S-30 & 77.5 & 6006.25 \\
\hline 31 & S-31 & 60 & 3600 \\
\hline 32 & S-32 & 30 & 900 \\
\hline \multicolumn{2}{|c|}{ TOTAL } & 1515 & 86450 \\
\hline \multicolumn{2}{|c|}{ LOWEST SCORE } & 15 & \\
\hline \multicolumn{2}{|c|}{$\begin{array}{l}\text { HIGHEST } \\
\text { SCORE }\end{array}$} & 97.5 & \\
\hline
\end{tabular}




\begin{tabular}{ll}
\hline MEAN & 47.34 \\
\hline MODE & 30 \\
\hline MEDIAN & 40 \\
\hline STANDARD & 21.79 \\
DEVIATION & \\
\hline
\end{tabular}

The result of student's Grammar mastery showed that the lowest score was 15, while the highest score was 97.5. The mean of score was 47.34, mode of score was 30, median of score was 40, and standard deviation of score was 21.79. Then, it included five level of students Grammar mastery score. The distribution detail saw at the table below:

Table 3. The Distribution of Students Grammar Mastery

\begin{tabular}{cccc}
\hline Category & Score Interval & Frequency & Percentage \\
\hline Excellent & $80-100$ & 3 & $9.375 \%$ \\
\hline Good & $66-79$ & 4 & $12.5 \%$ \\
\hline Enough & $56-65$ & 2 & $6.25 \%$ \\
\hline Less & $40-55$ & 9 & $28.125 \%$ \\
\hline Fail & $30-39$ & 14 & $43.75 \%$
\end{tabular}

\section{Result of Vocabulary Size Test}

Vocabulary size test was 90 items matching test that divided into three-level. They were 3000 level, 6000 level, and academic vocabulary level of the word. It adopted by Vocabulary Level Test Version 2 by Paul Nation as cited Bayazidi \& Saeb (2017, p. 37). The researcher conducted the test by using Google Form which should answer in 100 minutes.

Table 4. The result of Vocabulary Size Score as Variable X2

\begin{tabular}{ccccc}
\hline No & Code & Total & $\mathbf{X 2}$ & $\mathbf{X 2}^{2}$ \\
\hline 1 & S-1 & 31 & 34.44 & 1156 \\
\hline 2 & S-2 & 76 & 84.44 & 7056 \\
\hline 3 & S-3 & 54 & 60 & 3600 \\
\hline 4 & S-4 & 40 & 44.44 & 1936 \\
\hline 5 & S-5 & 83 & 92.22 & 8464 \\
\hline 6 & S-6 & 60 & 66.66 & 4489 \\
\hline 7 & S-7 & 74 & 82.22 & 6724 \\
\hline 8 & S-8 & 81 & 90 & 8100 \\
\hline 9 & S-9 & 75 & 83.33 & 6889 \\
\hline 10 & S-10 & 74 & 82.22 & 6724 \\
\hline 11 & S-11 & 43 & 47.77 & 2304 \\
\hline 12 & S-12 & 46 & 51.11 & 2601 \\
\hline 13 & S-13 & 70 & 77.77 & 6084 \\
\hline 14 & S-14 & 45 & 50 & 2500 \\
\hline 15 & S-15 & 66 & 73.33 & 5329 \\
\hline 16 & S-16 & 51 & 56.66 & 3249 \\
\hline 17 & S-17 & 10 & 11.11 & 121 \\
\hline 18 & S-18 & 84 & 93.33 & 8649 \\
\hline 19 & S-19 & 78 & 86.66 & 7569 \\
\hline 20 & S-20 & 80 & 88.88 & 7921 \\
\hline 21 & S-21 & 50 & 55.55 & 3136 \\
\hline
\end{tabular}




\begin{tabular}{|c|c|c|c|c|}
\hline 22 & S-22 & 38 & 42.22 & 1764 \\
\hline 23 & S-23 & 74 & 82.22 & 6724 \\
\hline 24 & S-24 & 74 & 82.22 & 6724 \\
\hline 25 & S-25 & 78 & 86.66 & 7569 \\
\hline 26 & S-26 & 86 & 95.55 & 9216 \\
\hline 27 & S-27 & 68 & 75.55 & 5625 \\
\hline 28 & S-28 & 14 & 15.55 & 256 \\
\hline 29 & S-29 & 27 & 30 & 900 \\
\hline 30 & S-30 & 76 & 84.44 & 7056 \\
\hline 31 & S-31 & 83 & 92.22 & 8464 \\
\hline 32 & S-32 & 30 & 33.33 & 1089 \\
\hline & & 1919 & 2132.22 & 159988 \\
\hline & SCORE & \multicolumn{3}{|c|}{11.11} \\
\hline & SCORE & \multicolumn{3}{|c|}{95.55} \\
\hline & & \multicolumn{3}{|c|}{66.63} \\
\hline & & \multicolumn{3}{|c|}{82.22} \\
\hline & IAN & \multicolumn{3}{|c|}{76.66} \\
\hline & $\begin{array}{l}\text { ARD } \\
\text { TION }\end{array}$ & \multicolumn{3}{|c|}{24.25} \\
\hline
\end{tabular}

Based on the table, it saw that the lowest score of student's vocabulary was 11.11 , while the highest was 95.55. The mean of students' vocabulary size score was 66.63 , the mode of the score is 82.22, the median score was 76.66 and the standard deviation was 24.25. The vocabulary size had a five-level category with different score interval that explained the table below:

Table 5. The Distribution of Students' Vocabulary Size

\begin{tabular}{cccc}
\hline Category & Score Interval & Frequency & Percentage \\
\hline Excellent & $80-100$ & 15 & $46.875 \%$ \\
\hline Good & $70-79$ & 3 & $9.375 \%$ \\
\hline Fair & $60-69$ & 2 & $6.25 \%$ \\
\hline Poor & $50-59$ & 4 & $12.5 \%$ \\
\hline Bad & $<50$ & 8 & $25 \%$ \\
\hline
\end{tabular}

\section{Result of Translation Test}

The translation test of this research was a paragraph of report text in Indonesia language that participants had to translate into the English language by using Google Form. The researcher gave 100 minutes and did not allow to use of Google Translate while doing the test. The result of the translation test interpreted the table below:

Table 6. The Result of Translation Score as Variable Y

\begin{tabular}{cccccc}
\hline \multirow{2}{*}{ NO } & \multirow{2}{*}{ CODE } & \multicolumn{2}{c}{ SCORE } & \multirow{2}{*}{ TOTAL } & \multirow{2}{*}{ FINAL } \\
\cline { 2 - 4 } & & GRADER 1 & GRADER 2 & & \\
\hline 1 & S-1 & 40 & 70 & 110 & 55 \\
\hline 2 & S- 2 & 35 & 74 & 109 & 54.5 \\
\hline 3 & S-3 & 40 & 78 & 118 & 59 \\
\hline 4 & S-4 & 40 & 60 & 100 & 50 \\
\hline
\end{tabular}




\begin{tabular}{|c|c|c|c|c|c|}
\hline 5 & S-5 & 30 & 84 & 114 & 57 \\
\hline 6 & S-6 & 30 & 65 & 95 & 47.5 \\
\hline 7 & S-7 & 35 & 75 & 110 & 55 \\
\hline 8 & S-8 & 40 & 70 & 110 & 55 \\
\hline 9 & S-9 & 35 & 75 & 110 & 55 \\
\hline 10 & S-10 & 30 & 74 & 104 & 52 \\
\hline 11 & S-11 & 30 & 65 & 95 & 47.5 \\
\hline 12 & S-12 & 40 & 78 & 118 & 59 \\
\hline 13 & S-13 & 30 & 75 & 105 & 52.5 \\
\hline 14 & S-14 & 25 & 60 & 85 & 42.5 \\
\hline 15 & S-15 & 60 & 85 & 145 & 72.5 \\
\hline 16 & S-16 & 40 & 80 & 120 & 60 \\
\hline 17 & S-17 & 45 & 65 & 110 & 55 \\
\hline 18 & S-18 & 35 & 78 & 113 & 56.5 \\
\hline 19 & S-19 & 30 & 76 & 106 & 53 \\
\hline 20 & S-20 & 30 & 80 & 110 & 55 \\
\hline 21 & S-21 & 40 & 78 & 118 & 59 \\
\hline 22 & S-22 & 30 & 68 & 98 & 49 \\
\hline 23 & S-23 & 30 & 75 & 105 & 52.5 \\
\hline 24 & S-24 & 30 & 78 & 108 & 54 \\
\hline 25 & S-25 & 30 & 78 & 108 & 54 \\
\hline 26 & S-26 & 40 & 80 & 120 & 60 \\
\hline 27 & S-27 & 35 & 75 & 110 & 55 \\
\hline 28 & S-28 & 30 & 60 & 90 & 45 \\
\hline 29 & S-29 & 30 & 60 & 90 & 45 \\
\hline 30 & S-30 & 35 & 80 & 115 & 57.5 \\
\hline 31 & S-31 & 30 & 75 & 105 & 52.5 \\
\hline 32 & S-32 & 30 & 65 & 95 & 47.5 \\
\hline \multicolumn{2}{|c|}{ TOTAL } & 1110 & 2339 & 3449 & 1724.5 \\
\hline \multicolumn{2}{|c|}{$\begin{array}{l}\text { LOWEST } \\
\text { SCORE }\end{array}$} & 25 & 60 & 85 & 42.5 \\
\hline \multicolumn{2}{|c|}{$\begin{array}{c}\text { HIGHEST } \\
\text { SCORE }\end{array}$} & 60 & 85 & 145 & 72.5 \\
\hline \multicolumn{2}{|c|}{ MEAN } & 34.68 & 73.09 & 107.78 & 53.89 \\
\hline \multicolumn{2}{|c|}{ MEDIAN } & 32.5 & 75 & 109.5 & 54.75 \\
\hline \multicolumn{2}{|c|}{ MODE } & 30 & 78 & 110 & 55 \\
\hline \multicolumn{2}{|c|}{$\begin{array}{l}\text { STANDARD } \\
\text { DEVIATION }\end{array}$} & 6.71 & 7.23 & 11.34 & 5.67 \\
\hline
\end{tabular}

According to data in table 4.5 above, two graders assessed the result of the translation test. Because translation needed the subjective assessment, the first-grader was the expert lecture of Translation that was qualified, and the second-grader was the researcher itself. The data of first graders saw that the lowest score of students translation was 25 , the highest score was 60 , the mean was 34.68 , the median was 32.5 , the mode was 30 , and the standard deviation was 6.71 . 
Then, the data of second graders showed that the lowest score was 60, the highest score was 85 , the mean was 73.09 , the median was 75 , the mode was 78 , and the standard deviation was 7.23. Both scores of first grader and second grader added and divided two by the researcher to have the final score. Based on the final score, the data showed the lowest score of students translation was 42.5 , the highest score was 72.5 , the mean was 5.89 , the median was 54.75 , the mode was 55, and the standard deviation was 5.67.

The translation level divided into five categories of translation scores. It showed in the table below:

Table 7. The Distribution of Students' Translation Ability

\begin{tabular}{cccc}
\hline Category & Score Interval & Frequency & Percentage \\
\hline Almost Perfect & $86-90$ & 0 & 0 \\
\hline Very Good & $76-85$ & 0 & 0 \\
\hline Good & $61-75$ & 1 & $3.12 \%$ \\
\hline Enough & $46-60$ & 28 & $87.5 \%$ \\
\hline Worse & $20-45$ & 3 & $9.37 \%$
\end{tabular}

Based on errors' interpretation of student's translation above, the researcher got the conclusion from first grader and second grader of common errors that faced by students translation. It showed in the table below:

Table 8. Students' Common Errors of Translation Test

\begin{tabular}{lll}
\hline No Sentence & \multicolumn{1}{c}{ Explanation } \\
\hline 1. In Japanese society, a geisha is \\
a woman who is professionally give the variety of "addition", thus \\
trained to entertain men, article " $a$ " could give at a certain \\
$\begin{array}{l}\text { especially businessmen in } \\
\text { restaurants parties. }\end{array}$
\end{tabular}




\begin{tabular}{|c|c|c|}
\hline & & $\begin{array}{l}\text { so, even then , nevertheless, and } \\
\text { nonetheless. }\end{array}$ \\
\hline \multirow[t]{5}{*}{5.} & \multirow{5}{*}{$\begin{array}{l}\text { Traditionally, geisha were like } \\
\text { indentured servants, left by } \\
\text { their parents to the geisha } \\
\text { houses to accommodate, feed, } \\
\text { and train them. }\end{array}$} & $\begin{array}{l}\text { Don't use preposition before adverb of } \\
\text { manner. }\end{array}$ \\
\hline & & $\begin{array}{l}\text { The word of "traditionally" showed the } \\
\text { time signal of past tense that followed } \\
\text { the context. It meant, the tenses used } \\
\text { past tense. }\end{array}$ \\
\hline & & $\begin{array}{l}\text { A lot students didn't use the word } \\
\text { "indentured", they prefer used the word } \\
\text { "bonded, tied up". Indenture itself } \\
\text { meant bind (someone) by an indenture } \\
\text { as an apprentice or laborer. It closer to } \\
\text { the context. }\end{array}$ \\
\hline & & $\begin{array}{l}\text { Commonly, the students used } \\
\text { "dormitory" to interpret "asrama". } \\
\text { Beside, based on background } \\
\text { knowledge of Geisha, Javanese were } \\
\text { called it by Geisha house or Geisha } \\
\text { quarter. }\end{array}$ \\
\hline & & $\begin{array}{l}\text { Because of there was "to", the next } \\
\text { word should use present pattern. Beside, } \\
\text { if it was without "to" it should use past } \\
\text { pattern. }\end{array}$ \\
\hline \multirow[t]{2}{*}{6.} & \multirow{2}{*}{$\begin{array}{l}\text { Most modern Geisha build an } \\
\text { association, even though the } \\
\text { profession as a whole has } \\
\text { declined since World War II. }\end{array}$} & $\begin{array}{l}\text { The phrase "modern Geisha" showed } \\
\text { the time signal "now", so it used present } \\
\text { pattern to describe it. }\end{array}$ \\
\hline & & $\begin{array}{l}\text { The word "association" more } \\
\text { appropriate than "unity/union" that used } \\
\text { by a lot students. Even so, it words were } \\
\text { understandable by the reader. }\end{array}$ \\
\hline & \multirow[t]{3}{*}{$\begin{array}{l}\text { Geisha have to quit their job } \\
\text { when they get married, and the } \\
\text { one who retire without being } \\
\text { married often become dance or } \\
\text { music teachers. }\end{array}$} & $\begin{array}{l}\text { Some students used "have to" and the } \\
\text { others used "must". Both of them were } \\
\text { correct translation. But, according to the } \\
\text { meaning, "have to" more appropriate in } \\
\text { this context. }\end{array}$ \\
\hline & & $\begin{array}{l}\text { The words "quit"and "stop" were used } \\
\text { by participants. Both of them were } \\
\text { correct translation, but the "quit" more } \\
\text { appropriate to use in this context. }\end{array}$ \\
\hline & & $\begin{array}{l}\text { Some students used "without married" } \\
\text { that married itself was adjective class. } \\
\text { Without should followed by noun or } \\
\text { gerund as like without being married, } \\
\text { without marriage, and without marrying } \\
\text { someone (should be followed by object). }\end{array}$ \\
\hline
\end{tabular}

\section{Correlation of Grammar Mastery and Translation Ability on Report Text}


Table 9. Correlation of Grammar Mastery and Translation Ability on Report Text Correlations

\begin{tabular}{|ll|r|r|}
\hline & \multicolumn{1}{|c|}{$\begin{array}{c}\text { Grammar } \\
\text { Mastery }\end{array}$} & \multicolumn{2}{c|}{$\begin{array}{c}\text { Translation } \\
\text { Ability }\end{array}$} \\
\hline Grammar & Pearson & 1 & $.590^{* *}$ \\
& Correlation & & .000 \\
& Sig. (2-tailed) & 32 & 32 \\
& $\mathrm{~N}$ & $.590^{* *}$ & 1 \\
Translation & Pearson & & \\
Ability & Correlation & .000 & 32 \\
& Sig. (2-tailed) & & \\
& $\mathrm{N}$ & & \\
& **. Correlation is significant at the 0.01 level (2-tailed).
\end{tabular}

The researcher calculate the data by using SPSS 18. The table 4.15 interprets the Pearson Product Moment Correlation Coefficient is 0.590 at the 0.01 or $1 \%$ level of significant. Then, the Significant (2-tailed) is 0.000 which lower than 0.05 . Accorded to calculation of degree freedom, if $r_{\text {count }}>r_{\text {table, }}$ there is significant correlation between variables. On the contrary, if $r_{\text {count }}<r_{\text {table, }}$ there is no significant correlation between variables. In this case, $r_{\text {table }}=\mathrm{N}-2,32$ $2=30, r_{\text {table }}=0.463$. It explains that $r_{\text {count }}>r_{\text {table }}=0.590>0.463$, and the significant (2-tailed) $0.000<0.05$, which means there is correlation between grammar mastery and translation ability on report text. Thus, there is a significant correlation between grammar mastery and translation ability on report text.

\section{Correlation of Vocabulary Size and Translation Ability on Report Text}

Table 10. Correlation of Vocabulary Size and Translation Ability on Report Text Correlations

\begin{tabular}{|ll|r|r|}
\hline & \multicolumn{1}{|c|}{$\begin{array}{c}\text { Vocabulary } \\
\text { Size }\end{array}$} & \multicolumn{2}{c|}{ Translation } \\
Ability
\end{tabular}

*. Correlation is significant at the 0.05 level (2-tailed).

The table shows that data of Pearson Correlation Coefficient is 0.395 at 0.05 or $5 \%$ level of significant. Then the value of Significant (2-tailed) is 0.025 which is $0.025<0.05$. The number of students is 32 that must minus (-) 2 to get $r_{\text {table, }}$, it is $r_{\text {table }}=\mathrm{N}-2,32-2, r_{\text {table }}=0.361$. If $\left.r_{\text {count }}\right\rangle$ $r_{\text {table, }}$ there is any significant correlation between variables. On the contrary, if $r_{\text {count }}<r_{\text {table, }}$ there is no any significant correlation between variables. Accorded to the data, it explains that Significant (2-tailed) is $0.025<0.05$, and $\mathrm{r}_{\text {count }}>\mathrm{r}_{\text {table }} 0.395>0.361$ which means there is 
correlation of vocabulary size and translation ability. Thus, there is a significant correlation between students' vocabulary size and translation ability on report text.

\section{Correlation among Grammar Mastery, Vocabulary Size, and Translation Ability on Report Text}

Table 11. Correlation Among Grammar Mastery, Vocabulary Size, and Translation Ability on Report Text

Model Summary

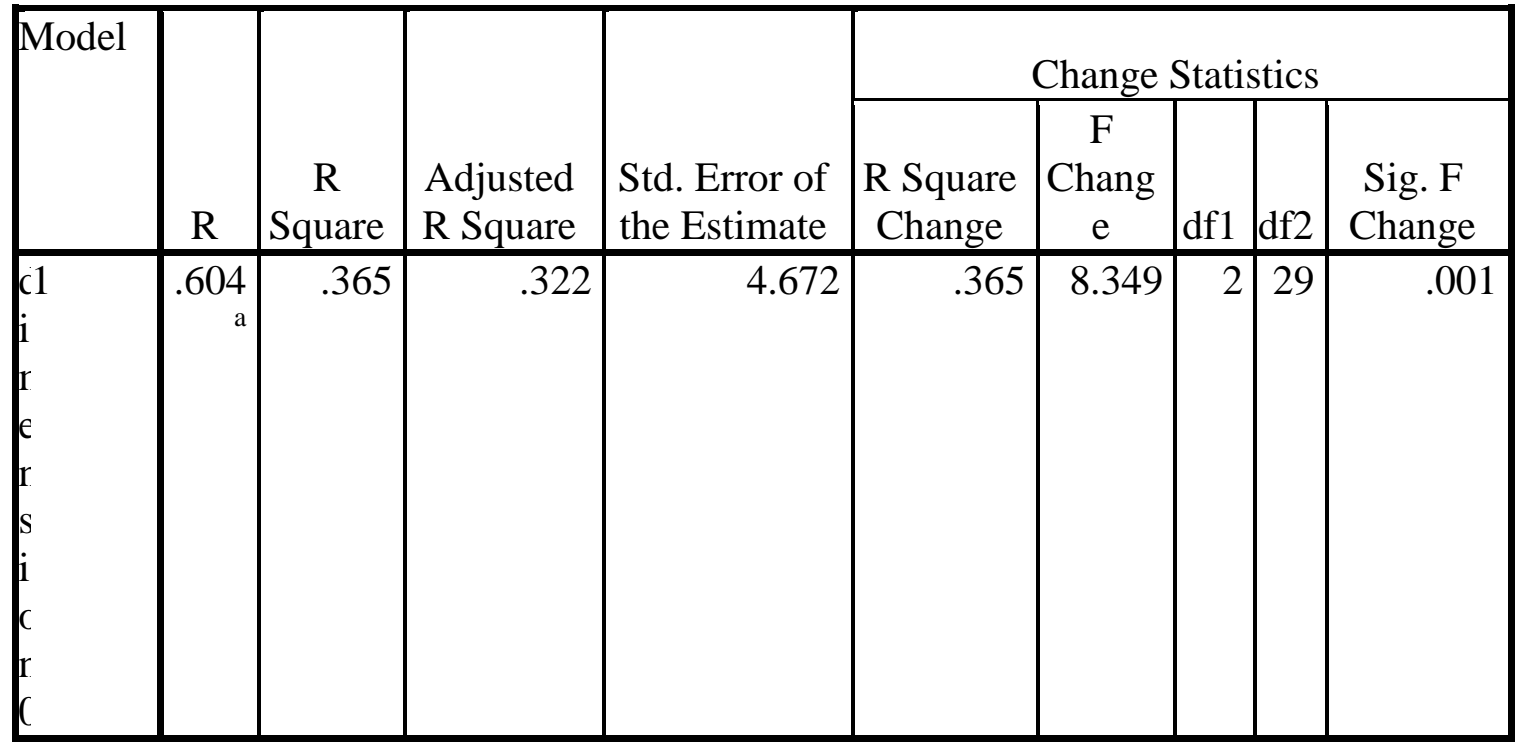

a. Predictors: (Constant), Vocabulary Size, Grammar Mastery

Based on model summary table, correlation coefficient among grammar mastery, vocabulary size on translation ability is 0.604 . As the researcher explained at chapter 3 , the value range of 0.604 is strong category. Then, the table shows the Significant F Change is 0.001 which means $0.001<0.05$. In addition, the contribution of grammar and vocabulary size delivers $36.5 \%$, while $63.5 \%$ the other variables. It explains the alternative hypothesis (Ha) was accepted, and the null hypothesis (H0) was rejected.

After that, the researcher measures the Multiple Determinant Coefficient (MDC) to prove the variance distribution of a dependent variable (Y) that analyze by linear regression and independent variable $(\mathrm{X})$ :

$\mathrm{MDC}=(\mathrm{rx} 1 \mathrm{x} 2 \mathrm{y}) 2 \times 100 \%$

$\mathrm{MDC}=(0.604) 2 \times 100 \%$

$\mathrm{MDC}=36.48 \%$

The table interprets result data of $\mathrm{F}$ change is 8.349 , df1 is 2 , and df2 is 29 . Also, the researcher looks at $\mathrm{F}$ table score compares with $\mathrm{F}$ change. They were $\mathrm{F}$ change $>\mathrm{F}$ table $=8.349>3.33$, which concludes there is a significant correlation among students' Grammar mastery and Vocabulary toward Translation ability on report text.

\section{Discussion}

As stated in Merc (2019), the translation is influenced by some factors that one of them are using of grammar and lexical in text. In this case, the students' grammar mastery have common 
errors of article and tense use. According to Oxford Dictionary, Stevenson (2010), tense is the transformation of verb that influenced certainly time and place. The verb transformation while translating report text presents and creates the arduous thing. For the example, the report text generally use present tense, but if tense's context is straightforward to another tense, we shall follow it first, then rebound the original one. Generally, Putri (2019) stated that students EFL help by mastering grammar, especially while translating SL into TL. It includes the consideration on grammar. In addition, The previous research that conducted by Oktari, Mukhtar, \& Arasuli (2019) believed that the students difficulties grammar when they translate the text is determine the sentence patterns while producing the text.

According to Merc (2019), the cultural of native language affect on diction. The lot of students have lack of knowledge that generate them use inappropriate vocabulary. Besides, demanding students of translating report text to avoid the errors diction find out the background knowledge of context. In this case, the context tell "a Geisha" that students must master "the Geisha" material before translate it. Based on Robinson (2019), the one of nine aspects of translator reliability have to the detail attention on distinct context and collocation. The selection vocabulary have to exactly compatible on background knowledge to release the good translation. For the example, some students use the word "bitch" to interpret the "prostitute". As a context, Geisha is an artist. So the word "bitch" inappropriate to the background knowledge. The improper of vocabulary is effected by minimum students' size vocabulary. They do not have a number variety of word that use in translating.

Based on Utami (2017, p. 192), when students' transference sentence pattern of Indonesia English, there is the two problem, which is the students' mother tongue (SL) and lack of knowledge. In this case, the researcher points are grammar and vocabulary size toward students' translation ability. When students translate the text, they shall master grammar to create the improper sentence, and the intensity of vocabulary that the evidence among them explains at the previous sub-chapter. Who do not mastered them well, the errors translation will take effect. Both variables that mention at the previous study which are the correlation between grammar mastery on translation ability and vocabulary size on translation are analogously with the result of this research. Even though the researcher does not invent the study who conducts among three variables, the result data and statement of previous study prove that there is correlation among grammar mastery and vocabulary size toward translation ability on report text.

\section{CONCLUSION}

The conclusion that consider SPSS 18.0 program that believe by the researcher are:

1. The alternative hypothesis was obtained which grammar mastery and translation ability on report text showed up the positive correlational at seventh semester of English Study Program in academic year 2017/2018 in State Islamic University Palangka Raya. It proved by $r_{\text {count }}>r_{\text {table }}(0.590>0.463)$. It means the mastering grammar at students significantly influence translation ability.

2. The alternative hypothesis between vocabulary size and translation ability on report text was accepted which showed up the positive correlational at seventh semester of English Study Program in academic year 2017/2018 in State Islamic University Palangka Raya at $r_{\text {count }}>r_{\text {table }}(0.395>0.361)$. It means the number of vocabulary that students know, the quality ability of translation appears.

3. The correlation among grammar mastery and vocabulary size toward translation ability on report text were proved by the statistic data of value range of 0.604 , Significant F Change 
$0.001<0.05$, and the contribution of grammar and vocabulary size delivered $36.5 \%$, while $63.5 \%$ the other variables.

\section{ACKNOWLEDGMENTS}

Alhamdulillahi rabbil 'alamin, the researcher thanks to Allah for his blessings, love, and mercy her whole life while finishing this article. Also, Sholawat and Salam to our Prophet Muhammad SAW that bring our life from the darkness to the brightness. This article entitled "Correlation Among Grammar Mastery and Vocabulary Size Toward Translation Ability on Report Text" is submitted as the final requirement in accomplising research paper at English Education Study Program State Islamic Institute of Palangka Raya.

\section{REFERENCES}

Azam, A. (2014). Teaching Grammar and Vocabulary. Journal of Advances in Linguistics, 2(1), $61-79$.

Bayazidi, A., \& Saeb, F. (2017). Assessing Reliability of Two Versions of Vocabulary Levels Tests in Iranian Context. Advances in Language and Literary Studies, 8(1), 30-43.

Berg, R. Van den. (2014). Juara satu dan dua: Membandingkan situasi kebahasaan Indonesia dan Papua Nugini. Linguistik Indonesia, 32(2), 103-130.

Creswell, J. W. (2012). Educational Research (4th ed.). Lincoln: University of Nebraska.

Debata, P. K. (2013). The Importance of Grammar In English Language Teaching: A Reassessment. Language in India, 13(5), 482-486.

Hasan, \& Subekti, N. B. (2017). The Corelation Between Vocabulary Mastery and Writing Skill of Secondary School Students. JELLT (Journal of English Language and Language Teaching), 1(2), 55-60.

Jixing, L. (2013). Translation Definitions in Different Paradigms. Canadian Social Science, 9(4), 107-115.

Merc, A. (2019). L1 to L2 Translation Practices in Foreign Language Teacher Education: Student Teachers' Views. Journal of International Cooperation and Development, 2(1), 10.

Oktari, F., Mukhtar, M., \& Arasuli, A. (2019). The Correlation Between Students' Grammar Mastery and Their Translation Ability. JALL (Journal of Applied Linguistics and Literacy), $3(2), 144-152$.

Putri, N. Z. (2019). The Correlation Between Grammar Mastery and Translation Ability of English Department Academic Year 2015 Students At IAIN Palangka Raya. Thesis Unpublished: State Islamic University Palangka Raya.

Richards, J. C., \& Schmidt, R. (2010). Longman dictionary of language teaching and applied linguistics (4th ed.). Great Britain: Pearson Education Limited.

Robinson, D. (2019). Becoming a Translator: An Introduction to the Theory and Practice of Translation. New York: Routledge.

Stevenson, A. (2010). Oxford Dictionary of English. New York: Oxford University.

Utami, S. (2017). The Source of Errors in Indonesia English Translation. Jurnal Kata: Penelitian Tentang Ilmu Bahasa Dan Sastra, 1(2), 192-202. 